15 - Molecular Structure Determination by Methods other than Diffraction

16 - Symmetry and its Generalization

17 - Data Handling and Communication

18 - Crystallographic Teaching and the History of Crystallography

19 - Industrial Crystallography.

On behalf of the Programme Committee, I now invite you to submit the proposals for:

Topics and speakers for Main Lectures

Topics, chairpersons and speakers for the Microsymposia

Any revision of the list of categories

Other matters concerning the scientific programme.

The following Satellite Meetings are planned:

1. Hefei School on Crystallographic Computing

2. Neutron Scattering

3. Powder Diffraction

4. Synchrotron Radiation in Crystallography

5. Molecular Structure.

All of these Satellite Meetings will be organized by, or in conjunction with, the relevant Commissions of the Union.

The memberships of the Programme Committee and Organizing Committee are given below.

Please send me your proposals by 28 February 1992, at the latest. This deadline is necessary to give adequate time for consultations before the scientific programme is finalized in mid 1992 by the Programme Committee. Replies received after 28 February will not be considered.

XIAO-JIE XU Chairman of the Programme Committee

\section{Programme Committee}

Chairman: Xiao-jie Xu (China)

Members: A. Authier (France), W. L. Duax (USA), J. R. Helliwell (UK), W. G. J. Hol (The Netherlands), Y. Katsube (Japan), F. Liebau (Germany), Y. Le Page (Canada), V. I. Simonov (USSR) and J. W. White (Australia)

Secretary: Lu-hua Lai

\section{Organizing Committee}

Chairman: Mei-cheng Shao

Vice-Chairmen: Jing-kui Liang and Jin-ling Huang Chief Secretaries: Tie-liang Wang, Hui Liu and Xiang-lin Jin

The address for Xiao-jie $\mathrm{Xu}$ and Mei-cheng Shao is:

Department of Chemistry

Peking University

Beijing 100871

China

Fax: (861)2564095
Acta Cryst. (1992). A48, 78

\section{Nominations for the Ewald Prize}

The International Union of Crystallography is pleased to invite nominations for the Ewald Prize for outstanding contributions to the science of crystallography. The Prize is named after Professor Paul P. Ewald, in recognition of his significant contributions to the foundations of crystallography and to the founding of the International Union of Crystallography. Professor Ewald was the President of the Provisional International Crystallographic Committee from 1946 to 1948, the first Editor of the Union's publication Acta Crystallographica from 1948 to 1959 and the President of the Union from 1960 to 1963.

The Prize consists of a medal, a certificate and a financial award, and is presented once every three years during the triennial International Congresses of Crystallography. The recipients to date are as follows:

$\begin{array}{cll}\text { Year } & \text { Place } & \text { Recipients } \\ 1987 & \text { Perth, Australia } & \begin{array}{l}\text { Professor J. M. Cowley and } \\ \text { Dr A. F. Moodie }\end{array} \\ 1990 & \text { Bordeaux, France } & \begin{array}{l}\text { Professor B. K. Vainshtein. } \\ \end{array}\end{array}$

The third Prize, for which nominations are now being invited, will be presented at the XVI Congress in Beijing, China, in August 1993.

Scientists who have made contributions of exceptional distinction to the science of crystallography are eligible for the Ewald Prize, irrespective of nationality, age or experience. The Selection Committee will give careful attention to the nominations of outstanding scientists who have not yet won a major prize. Either an exceptionally distinguished scientific career or a major scientific accomplishment may be recognized. Current members of the Prize Selection Committee and the President of the Union are not eligible. No restrictions are placed on the time or the means of publication of the nominee's contributions. The Prize may be shared by more than one contributor, but not more than three, to the same scientific achievement.

Nominations for the Ewald Prize should be submitted in writing, preferably using the Ewald Prize Nomination Form and accompanied by supporting documentation, to the Executive Secretary of the International Union of Crystallography, 5 Abbey Square, Chester CH1 2HU, England, from whom copies of the Nomination Form, the names of the Selection Committee and advice on the submission of nominations may be obtained. The closing date for nominations is 31 August 1992.
A. Authier
President

A. I. HORDVIK General Secretary 